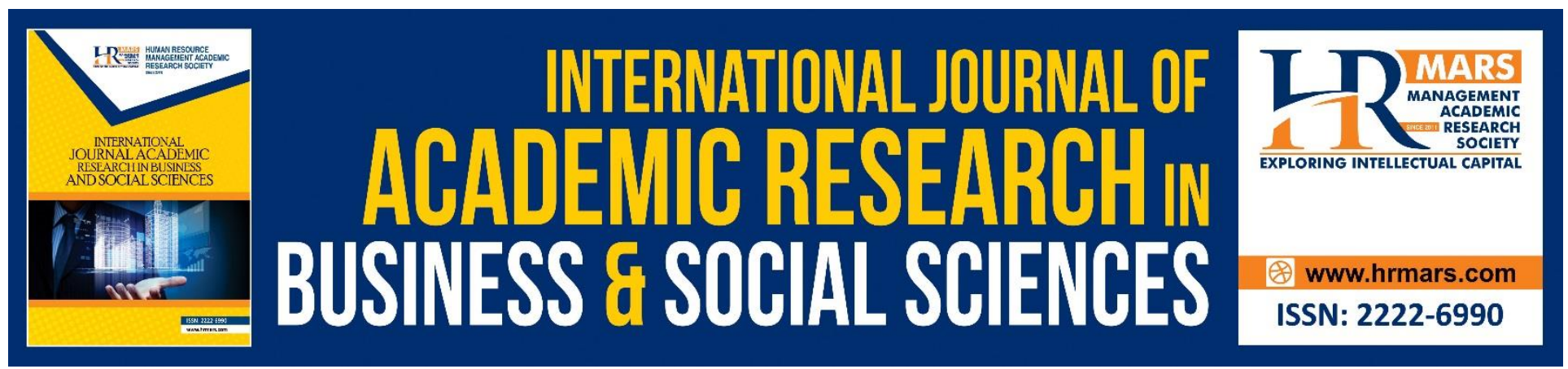

\title{
Big Five Personality Characteristics: An Exploratory Study on Bumiputra SMEs in Malaysia
}

Ibrahim Tijjani Sabiu, Fakhrul Anwar Zainol, Wan Norhayate Wan Daud, Norfadzilah Rashid, *Asyraf Afthanorhan

To Link this Article: http://dx.doi.org/10.6007/IJARBSS/v8-i12/5080 DOI: $10.6007 /$ IJARBSS/v8-i12/5080

Received: 27 Nov 2018, Revised: 18 Dec 2018, Accepted: 28 Dec 2018

Published Online: 30 Dec 2018

In-Text Citation: (Sabiu, Zainol, Daud, Rashid, \& Afthanorhan, 2018)

To Cite this Article: Sabiu, I. T., Zainol, F. A., Daud, W. N. W., Rashid, N., \& Afthanorhan, A. (2018). Big Five Personality Characteristics: An Exploratory Study on Bumiputra SMEs in Malaysia. International Journal of Academic Research in Business and Social Sciences, 8(12), 866-881.

Copyright: (C) 2018 The Author(s)

Published by Human Resource Management Academic Research Society (www.hrmars.com)

This article is published under the Creative Commons Attribution (CC BY 4.0) license. Anyone may reproduce, distribute, translate and create derivative works of this article (for both commercial and non-commercial purposes), subject to full attribution to the original publication and authors. The full terms of this license may be seen

at: http://creativecommons.org/licences/by/4.0/legalcode

Vol. 8, No. 12, 2018, Pg. 866 - 881

http://hrmars.com/index.php/pages/detail/IJARBSS

JOURNAL HOMEPAGE

Full Terms \& Conditions of access and use can be found at http://hrmars.com/index.php/pages/detail/publication-ethics 


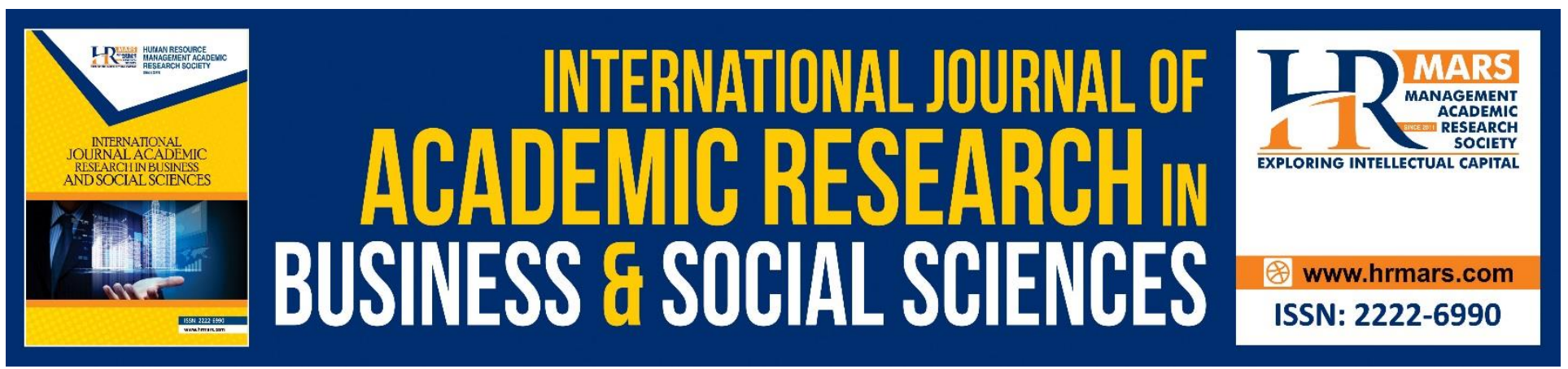

\title{
Big Five Personality Characteristics: An Exploratory Study on Bumiputra SMEs in Malaysia
}

\author{
Ibrahim Tijjani Sabiu, Fakhrul Anwar Zainol, \\ Wan Norhayate Wan Daud, Norfadzilah Rashid, *Asyraf Afthanorhan \\ Faculty of Economics and Management Sciences, Universiti Sultan Zainal Abidin, Terengganu, \\ Malaysia \\ *Corresponding Author: fakhrulanwar@unisza.edu.my
}

\begin{abstract}
Big five personality characteristics have proved to be a germinal personality theory providing insight scientifically into the causal factors that mold a person's capabilities and bearing towards a purpose. However, in spite that the significance of this personality theory to personality research and the potentiality of these factors, few studies used this model on a Bumiputras sample in Malaysia. Hence, this paper highlights the significance of using Big five personality characteristics by exploring the personality characteristics of the Bumiputra entrepreneurs using the Big Five. The study was based on a pilot study conducted of a 100 Bumiputra entrepreneurs that are being supported by government agencies. Therefore, Exploratory Factor Analysis was adopted in extracting the relevant factors in the analysis. The eventual analysis resulted in two of the dimensions being significant which are conscientiousness and openness to experience, and the other three dimensions were found to be not significant. This finding was corroborated by previous studies done on big five which also revealed the prevalence of some of the dimensions in some societies, while the dearth of some dimensions concurrently. This indicates that the Bumiputra Malays in Terengganu are generally more reserved just as expected by their communitarian society ethics, values and traditions teach them politeness, courteousness and respectfulness. However, this raises the question whether the values conflict with the general notion of aggressiveness "survival of the fittest" thing of the current business world.
\end{abstract}

Keywords: Big Five Personality, Entrepreneurship, Government Support, Bumiputra.

\section{Introduction}

According to Global Entrepreneurship Monitor (GEM) Malaysia Report (2011), there is a wide agreement on the significance of entrepreneurship to economic development. In USA, an estimate of almost half of its economic growth is achieved through entrepreneurship (Carraher et al., 2010). According to Abdullah (1999) and Ariff \& Abubakar (2003), right from 1970s, Malaysian government 
INTERNATIONAL JOURNAL OF ACADEMIC RESEARCH IN BUSINESS AND SOCIAL SCIENCES Vol. 8, No. 12, Dec, 2018, E-ISSN: 2222-6990 @ 2018 HRMARS

realized the immense importance of entrepreneurship as the main source of job creation, and source of wealth creation. Entrepreneurship development appeared to be the route to salvage the economic disparity between the Bumiputras (Malaysian indigenous people, mostly the Malays and other ethnic groups from Sabah and Sarawak) and other races (Chinese and Indians) (Ismail et al., 2009; Zamberi \& Xavier, 2012).

The Malays in these states are the dominant and most relevant in the history of the Malaysian entrepreneurship development. They are commonly known to be Muslims engrossed in their customs (adats) and cultures, enjoying the inalienable rights and privileges of the Bumiputras ordained for them under the constitution (Federal Constitution, Article 153). These rights were conferred on the Malays being the indigenous people in Malaysia so as to compensate them for the imposition of the other immigrant races of Chinese and Indians on them by the British colonists. These other races had massive influx into Malaysia during the early $20^{\text {th }}$ century as a result of the boom in the tin and rubber production in Malaysia, and subsequently, got citizenship status during the independence era (Alam et al., 2015; Hamidon, 2009).

Significantly, scholars highlighted the momentousness of entrepreneurship in propelling economic growth, employment as well as livelihood creation, and social status upliftment of a society towards development (Ariff \& Abubakar, 2005; Rose et al., 2006; Xavier, 2012; Teoh \& Chong, 2014). Equally, entrepreneurship development initiatives are intended to alleviate poverty of a society (Halim et al. 2014). However, Terengganu appeared to be among leading states in the Peninsular with the highest poverty rate of 31\% in 1990, 2006 at 15.4\% and only 4\% by 2012 recently (Roddin et al., 2011; Penang Monthly, 2012, June 27).

In addition, as Zainol and Ayadurai (2011) posited that the significance of indigenous entrepreneurship makes more indigenous people to be more engaged in entrepreneurship in order to ameliorate their socio-economic and living standards. Hence, according to the National Census 2010, Department of Statistics Malaysia, Terengganu constitutes $97.0 \%$ of Bumiputra population, making it the most densely Bumiputra populated state among the 13 states in the Peninsular Malaysia could have benefitted from the indigenous entrepreneurship. However, Terengganu has remained among the least developed states in Peninsular Malaysia. Though in terms of GDP per capita, it is among the leading states due to petroleum production (Mansur \& Ali, 2010).

Similarly, micro businesses flooded Terengganu, meanwhile the business environment often seems hostile to them. Entrepreneurs face challenges due to vulnerability to stiff competition, incompetency and entrepreneurial personality to mention a few. Worse more, the government support could not achieve the much desired impact here (Halim et al., 2012, 2014; Khalique et al. 2011; Sidek \& Zainol, 2011). Particularly, Mansor and Ali (2010) emphasized inability to compete, incompetency and drive among issues hampering business owners in Terengganu. They added that the entrepreneurs regard the business as a hobby or temporary, thus lacking the confidence to tackle the challenges independently towards success.

Halim et al., (2012) have asserted that the support provided by the government has been weak in developing the entrepreneurial personality needed in achieving business performance. As studies have proven that though there were numerous government supports in place, the Bumiputra entrepreneurs' failure in business has been quite alarming (Roddin et al., 2011). 
Furthermore, Hamidon, (2009) asserted that the Bumiputras are said to be more dependent on government assistance because they lack capital base, entrepreneurial skills and experience, innovativeness and persistence. Though, the government concentrated focus and concerted efforts towards Bumiputra that had hitherto enjoyed privileges and support right from 1970, the Bumiputra entrepreneurship still lagged behind compared to the non-Bumiputras. Hamidon (2014) added that the government rescue mission in assisting the Bumiputra did not trigger their entrepreneurship skills to a great extent. It rather braced the other races like the Chinese to being more persistent, competitive and productive. And they stood strong to achieve a lot more than the pampered Bumiputras whose achievement in equity ownership had been pathetic (Koon, 1997 \& Gomez, 2012). Indeed, one could ponder why the Chinese businesses prospered despite facing a great deal of challenges and thus, flourished against all odds contrary to the Bumiputras that are being pampered. As McGrath et al. (1992) noted, it could be that their (Chinese) Confucian ethic of hard work that propel them to strive against precarious environments.

A considerable number of theories and empirical studies suggested that personality characteristics form important determinants of the entrepreneurial intention and subsequent firm performance (Costa \& McCrae, 1992; Zhao et al., 2010; Patel \& Thatcher, 2012). Moreover, as argued by Ang and Hong, (2000) what defines an entrepreneur, is a composition of personality characteristics, motivation to enter, persist and succeed in an entrepreneurial venture. Mostly, all personality characteristics can be categorized into the 'big five personality' dimensions. McCrae and Costa (1987). Big five personality' characteristics have proved to be a germinal personality theory providing insight scientifically into the causal factors that mold a person's capabilities and bearing towards a purpose. However, in spite that the significance of big five to personality researches and the potentiality of these factors, few studies used this model on a Bumiputras sample in Malaysia (Ismail et al., 2009).

Therefore, this study intended to take a peep into the personality characteristics by exploring the personality characteristics of the Bumiputra entrepreneurs using Big Five Personality Traits.

The subsequent sections of this paper dealt with the big five personality characteristics, the methodology, results and conclusion.

\section{Entrepreneurship and Personality Characteristics}

Indeed, studies in entrepreneurship via psychology approach emphasized that entrepreneurship has significance. In view of this statement, some studies analysed the correlation between entrepreneurship and personality characteristics and added that entrepreneurs act in self-controlled, self-confident and competitive manner with great imagination and tending to avoid risks. Other studies considered motivation such as motivation for achievement, power distance and willingness for taking risks behind entrepreneurial behavior (Kalkan \& Kaygusuz, 2012).

Similarly, psychologists in entrepreneurship field evaluate performance in terms of market performance to determine entrepreneurial performance. They considered measurements like coping with stress, motivation, ability and knowledge in order to evaluate psychological characteristics of entrepreneurs. Psychological approach examines the process through which entrepreneurs psychological characteristics translate into success in entrepreneurship (Kalkan \& Kaygusuz, 2012). 
Personality is described as an individual's inclination to display some kind of reaction to different situations he or she is exposed to, and also maintaining that attitude steady and enduring it over time. Entrepreneurs exhibit certain characteristics that distinguish from non-entrepreneurs (Sidek \& Zainol, 2011). A number of researches have acknowledged that the entrepreneur is the key pivotal element to the process of founding and establishing a new business venture. And the entrepreneur remains the driving force that motivates and continuously energize the entrepreneurial process (Naffziger et al, 1994; Owens, 2003).

Williams (2011) asserted that the individual entrepreneur makes the decision to act entrepreneurially, takes the necessary actions to build and sustain the venture's performance. Shaver and Scott $(1991,39)$ made significant point to the integration of the psychological perspective. They noted"......we need a person, in whose mind all the possibilities come together, who believes that innovation is possible, and who has the motivation to persist until the job is done".

Similarly, there has been preponderance of definitions on who is an entrepreneur, with meager work done on the impact of personality on entrepreneurial performance and behavior. The personality characteristics predisposing an individual to take entrepreneurship as a career may not be same that lead to entrepreneurial success (Owens, 2003). Personality traits had been suitable predictors of several entrepreneurial behavior dimensions such as intention to start a business, success in running it and enhancing the growth of the firm (Shaver \& Scott, 1991).

Personality characteristics may also impact the entrepreneurial process (Klein, 1989). Motivated behavior is a function of both the person and the environment. Over the years, scholars have studied hundreds of traits and characteristics with the aim of discerning individual differences in motivated behavior. It was upon the much concentration of works by Atkinson, McClelland and some other researchers to study the need for achievement, the study of other entrepreneurial characteristics emerged. Among the mostly studied entrepreneurial traits are the psychological traits and "environmental push" traits as categorized by Brockhaus and Nord (1979) upon a comprehensive review of the entrepreneurship literature. Brockhaus (1986) included locus of control, risk-taking propensity and personal values in addition to need for achievement later in a subsequent review. Intentions and the practical purposiveness of the individual actions (Bird, 1988), self-efficacy, proactiveness versus aggressiveness (Lafaid, 1994).

Similarly, Sexton and Bowman (1986) studied a combination of nine personality traits in order to develop a personality profile unique to entrepreneurs or business students that are different from managers. Additionally, Solomon and Winslow (1988) explored the characteristics of 61 entrepreneurs and revealed these; confident, optimistic, taking calculated risks, self-assertive, independent and self-reliant, as those defining successful entrepreneurs (Lafaid, 1994).

However, Robinson et al., (1992) in their work, recognized achievement, personal control, innovation, self- esteem and opportunism. Again, Morriss and Sexton (1996) posited that the major determinants influencing entrepreneurial attitudes and behavior were innovation, risk-taking, and pro-activeness. And same year, Lumpkin and Dess (1996) included autonomy, risk-taking, proactiveness and 
competition aggressiveness in their definition of entrepreneurial orientation. In McClelland's (1987) work, he discovered competency areas for successful entrepreneurs as being relevant to studying their behaviors. Pro-activeness, achievement-oriented and strong commitment to business partners were observed and these were consistent with his previous work on the need for achievement.

McClelland made a tremendous effort to understanding the entrepreneur's personality during his career. McClelland (1961) categorically proposed "need for achievement" or nAch as key personality characteristics of entrepreneurs. He contended that entrepreneurs regarded as high achievers have strong desire and relentless aspirations by pursuing challenging set goals. And also, the entrepreneurs are invariably scaling up their performances in strive for excellence and superior performance (Lafaid, 1994).

However, subsequent researchers have not spared McClelland's work on the need for achievement as they criticized that the measure had deficiency in differentiating entrepreneurs and professionals like managers (Brockhaus \& Hortwitz, 1986). The definition of entrepreneurs as given by McClelland was too inclusive. Lastly, the construct lacked predictive value for it failed to find an established linkage between high need for achievement motivation and the decision to start a business in any study.

Most of recent researches in entrepreneurship field sought to determine what kind of personality traits may distinguish between entrepreneurs and non-entrepreneurs, and successful entrepreneurs from unsuccessful entrepreneurs. (Brockhaus, 1982; Brockhaus \& Horwitz, 1986; Ket de Vries, 1977; Lafaid, 1994; Lumpkin \& Dess, 1996). Again, personality and its impact on entrepreneurial outcomes had been debated for ages. Meanwhile the topic remains relevant, most especially as to the study Bumiputra entrepreneurs in Malaysia. In this study, personality characteristics is operationalized according to Costa and McCrae's (1988) Big Five Personality Characteristics. The dimensions of the big five are:

\section{Conscientiousness}

This is a personality dimension that describes an individual level of achievement orientation, work motivation, organization and planning. Individuals that have conscientiousness are achievementoriented who consistently exhibit behaviors or actions possessing self-efficacy. They are individual who accept traditional norms, virtue and take responsibility, that move them to enter entrepreneurship with the purpose of exploiting means in providing solution by refining the process to improve their environment. (Costa \& McCrae, 1992; Zhao et al. 2010; Patel \& Thatcher, 2012).

\section{Openness to Experience}

This dimension describes someone intellectually curious, imaginative, creative, adventurous, to try new ideas as well as alternative values and esthetic standards (Ismail et al., 2009). Entrepreneurs are seen as champions of creative thinking, being non-conventional is their way (Ciavarella et al., 2004; Patel \& Thatcher, 2012; Zhao et al., 2010). Entrepreneurs are adept to use their creativity, being tolerant and able to deal with stressful conditions and strategize within the resources constraints in order to solve their daily issues. Openness may not be consistently related to job performance in all occupations, but it showed significance in learning situations. Thus, successful entrepreneurs are often keen on acquiring knowledge to keep abreast of the changing needs, market trends, 
INTERNATIONAL JOURNAL OF ACADEMIC RESEARCH IN BUSINESS AND SOCIAL SCIENCES

Vol. 8, No. 12, Dec, 2018, E-ISSN: 2222-6990 @ 2018 HRMARS

competition or new technology encountered in the business. (Ismail et al., 2009; Patel \& Thatcher, 2012).

\section{Extraversion}

Extraversion describes socially active, outspoken, friendly, warm, vibrant, active, confident, and dominant persons in public gathering. They feel positive emotions and are mostly optimistic; they seek excitement and stimulation as this makes them accept entrepreneurship. Several important tasks involved in entrepreneurship require some form of social interaction. (Markman \& Baron, 2003). Extraverts are more competent overseeing the running of the venture, for that they are assertive, aggressive, presenting their views and visions, network effectively, and handle internal conflicts well (Baron \& Markman, 2003; Baum et al., 2001; Patel \& Thatcher, 2012).

\section{Emotional Stability}

Entrepreneurs high on emotional stability assume physical stress as they push hard where others may back down due to obstacles, snags or self-doubt. While, people low in emotional stability, feel worried, anxious; are equally vulnerable to hard situations; get affected by low self-esteem; got easily discouraged by negative feedbacks or failure (Patel \& Thatcher, 2012). Entrepreneurs assume considerable personal responsibility for success or failure of their own business, which those with high emotional stability are willing to take on (Zhao et al., 2010).

\section{Agreeableness}

This dimension describes a personality dimension that assesses one's attitudes and behavior towards others. Agreeable people are characterized as trusting, selfless, cooperative and modest. They tend to give in to other demands in the face of conflict. Entrepreneurship is centered on a profit-based enterprise set up mainly for the entrepreneur's self-interest, which the entrepreneur struggles hard to preserve at the expense of employers, partners, suppliers or even employees sometimes. Apparently, highly agreeable people are unlikely to find entrepreneurship attractive (Patel \& Thatcher, 2012; Zhao et al., 2010).

\section{Empirical Studies on Big Five Personality}

Some researchers have found personality quite related to entrepreneurial behavior and persistence. Others did not find any link, challenging the effect of personality traits on persistence (McClelland, 1965; Seibert \& Lumpkin, 2009; Brockhaus et al., 1986; Williams, 2011). Personality characteristics was operationalized by Big Five Personality Traits in the study. Zhao et al., (2010) in a meta-analysis of 60 studies found conscientiousness, extraversion, openness to experience, and emotional stability to be related with both entrepreneurial intention and entrepreneurial performance. Even though agreeableness was found otherwise, and the findings showed that personality predicts entrepreneurial intention and success. While, Zeffane (2013) proved that need for achievement motivation and extraversion variable of personality characteristics, played a significant role on entrepreneurial behavior. Similarly, Zhao and Wu (2014) asserted that positive relationship between personality characteristics and entrepreneurial motivation. As extraversion, openness and emotional stability correlated with entrepreneurial motivation, even though conscientiousness proved 
INTERNATIONAL JOURNAL OF ACADEMIC RESEARCH IN BUSINESS AND SOCIAL SCIENCES Vol. 8, No. 12, Dec, 2018, E-ISSN: 2222-6990 @ 2018 HRMARS

otherwise. Equally, Sabiu, Abdullah, and Amin (2017) in their study about the impact of motivation and personality characteristics on entrepreneurial persistence of Bumiputras in Malaysia found that motivation, conscientiousness and openness helped the Bumiputras in adopting more effective business attitudes towards their entrepreneurial persistence.

\section{Methodology}

Entrepreneurs being supported by the leading agency in Terengganu known as (Terengganu Entrepreneurship Development Foundation) were chosen to participate in this survey. The current study used primary data obtained through self-administered and mailed survey questionnaire. The questionnaire collected respondents' information on personality traits based on the inventory developed by John, Donahue and Kentle (1991).The Big Five Personality Traits was measured using 44 items that represent the prototype definitions developed through expert ratings. The inventory uses short phrases based on the trait adjectives known to be prototypical markers of the Big Five (John, 1989, 1990). Hence, the questions answered by the respondents were presented with a 7points Likert scale style as used in Kitchell (1997), whereby they indicated the extent they agree or disagree ranging from these ratings 1 for "strongly disagree" to 7 for "strongly agree".

A set of 100 questionnaires were gathered from the entrepreneurs to serve as pilot study to run Exploratory Factor Analysis and Reliability Test (Awang, 2012). After the data for the pilot was collected, it duly went through the process of data editing, mining to screen out odd responses, errors, missing values, double ticked responses and ambiguous statements (Sekaran \& Bougie, 2013). The data was first coded for the different variables on the instruments before the initial input of the data into SPSS Version 19. Coding of the data is essential to ease the analysis. The variables or items are abbreviated according to the construct name or variable name in SPSS and equally assigned numbers to easily identify the response for each respondent (Sekaran \& Bougie, 2013). . This was also done to all the dimensions of the big five personality characteristics of CONS1.....CONS9, OPEN1.....OPEN10, EXT1.....EXT8, EMS1.....EMS8 \& AGR1....AGR9 (refer to table 1 below). These codes keyed in would represent the variables in the SPSS. The responses were then keyed into SPSS according to the ticked value on the Likert scale from 1 to 7.

However, before proceeding to the EFA proper, the questionnaire negative items were taken note of, as they had to be reversed coded. These reverse coded items appear under the Independent Variable of Personality Characteristic. The "Conscientiousness" dimension had four (4) reverse coded items as CONS2_r, CONS4_r, CONS5_r and CONS9_r. The "Openness to Experience" had just two (2) reversed items as OPEN7_r and OPEN9_r. "Extraversion" dimension's had three (3) reversed items are EXT2_r, EXT5_r and EXT7_r. Meanwhile, "Emotional Stability" also was having three (3) reverse coded items, which are EMS2_r, EMS5_r and EMS7_r. And lastly, "Agreeableness" contained four (4) reversed items as AGR1_r, AGR3_r, AGR6 and AGR8_r as shown in table1. 
INTERNATIONAL JOURNAL OF ACADEMIC RESEARCH IN BUSINESS AND SOCIAL SCIENCES

Vol. 8, No. 12, Dec, 2018, E-ISSN: 2222-6990 @ 2018 HRMARS

Table 1: Items Codings of the Original Instrument

\begin{tabular}{|c|c|}
\hline Code & Indicators \\
\hline \multicolumn{2}{|c|}{ Personality Characteristics : Conscientiousness } \\
\hline Code & Indicators \\
\hline CONS1 & Does a thorough job \\
\hline CONS2_r & Can be somewhat careless (R) \\
\hline CONS3 & Is a reliable worker \\
\hline CONS4_r & Tends to be disorganized ( $R$ ) \\
\hline CONS5_r & Tends to be lazy at times $(\mathrm{R})$ \\
\hline CONS6 & Perseveres until the task is finished \\
\hline CONS7 & Does things efficiently \\
\hline CONS8 & Makes plans and follows through with them \\
\hline CONS9_r & Is easily distracted $(\mathrm{R})$ \\
\hline \multicolumn{2}{|c|}{ Personality Characteristics : Openness to Experience } \\
\hline Code & Indicators \\
\hline OPEN1 & Is original, comes up with new ideas \\
\hline OPEN2 & Is curious about many different things \\
\hline OPEN3 & Is ingenious, a deep thinker \\
\hline OPEN4 & Has an active imagination \\
\hline OPEN5 & Is inventive \\
\hline OPEN6 & Values artistic, aesthetic experience \\
\hline OPEN7_r & Prefers work that is routine and simple (R) \\
\hline OPEN8 & Likes to reflect, play with ideas \\
\hline OPEN9_r & Has few artistic interests $(\mathrm{R})$ \\
\hline OPEN19 & Is sophisticated in art, music or literature. \\
\hline \multicolumn{2}{|c|}{ Personality Characteristics : Extraversion } \\
\hline Code & Indicators \\
\hline EXT1 & Is talkative \\
\hline EXT2_r & Is reserved $(\mathrm{R})$ \\
\hline EXT3 & Is full of energy \\
\hline EXT4 & Generates a lot of enthusiasm \\
\hline EXT5_r & Tends to be quite $(R)$ \\
\hline EXT6 & Has an assertive personality \\
\hline EXT7_r & Is sometimes shy, inhibited (R) \\
\hline EXT8 & Is outgoing, sociable \\
\hline EXT9 & Is talkative \\
\hline \multicolumn{2}{|c|}{ Personality Characteristics : Emotional Stability } \\
\hline Code & Indicators \\
\hline EMS1 & Is depressed, blue \\
\hline EMS2_r & Is relaxed, handles stress well \\
\hline EMS3 & Can be tense \\
\hline EMS4 & worries a lot \\
\hline
\end{tabular}




\begin{tabular}{ll} 
EMS5_r & Is emotionally stable, not easily upset \\
EMS6 & Can be moody (R) \\
EMS7_r & Remains calm in tense situation \\
EMS8 & Gets nervous easily \\
Personality & Characteristics : Agreeableness \\
Code & Indicators \\
AGR1_r & Tends to find fault with others (R) \\
AGR2 & Is helpful and unselfish with others \\
AGR3_r & Starts quarrels with others (R) \\
AGR4 & Has a forgiving nature \\
AGR5 & Is generally trusting \\
AGR6_r & Can be cold and aloof (R) \\
AGR7 & Is considerate and kind to almost everyone \\
AGR8 & Is sometimes rude to others \\
AGR9_r & Likes to cooperate with others \\
\hline
\end{tabular}

\section{Method of Analysis}

At this stage, the Exploratory Factor Analysis which involves the Principal Component Analysis was carried out on the data. The essence of the EFA is considered as one of the procedure used to reduce data that involves grouping items sharing same characteristics under a particular component. And that way, it makes the data more manageable as minimum number of components deemed appropriate to show the maximum significance of the total variance of the main instrument. And equally, group the number of components that represent the entire data (Abdullah, 2010; Awang, 2012).

In the EFA, the Kaiser-Meyer-Olkin (KMO) which is a measure of the sample adequacy and Barlett's test of Sphericity are decided. A KMO of higher than 0.6 and closer to 1 is highly sought after (Awang, 2012). A Barlett's test of Sphericity showing the Chi-square and significant $p$-value $<0.000$ is mostly desirable. Also, in the EFA, the extraction involves grouping the items into possible component (s). The components having Eigenvalue closer to 1 or mostly above 1 are preferred. The Rotated Component Matrix is any item loading higher than 0.6 under a particular component and loading lower than 0.35 in another, be labeled into same group. However, if items having higher loading than 0.6 in one component and also higher than 0.35 in another (cross-loading), or those items having lower than 0.6 are subsequently dropped from the analysis (Awang, 2012).

\section{Results of the Exploratory Factor Analysis}

The "Personality Characteristics" construct which is a second order construct was analyzed (Awang, 2014). The 44 items spread out under 5 dimensions namely:

"Conscientiousness" is having 9 items coded as CONS1, CONS3, CONS7, CONS8 and the reversed coded as CONS2_r, CONS5_r, CONS9_r. The EFA of these items produced a KMO (0.696) which is satisfactory and Barletts's test of Sphericity (Chi-square $=237.301, \mathrm{p}$-value $<0.000$ ). It extracted and grouped the items into two (2) components: "Component1" has an Eigenvalue (3.125) with CONS1, CONS6, CONS7 and CONS8 in it. "Component2", with an Eigenvalue (1.614) include CONS2_r, 
INTERNATIONAL JOURNAL OF ACADEMIC RESEARCH IN BUSINESS AND SOCIAL SCIENCES Vol. 8, No. 12, Dec, 2018, E-ISSN: 2222-6990 @ 2018 HRMARS

CONS4_r, CONS5_rand CONS9_r. Meanwhile, CONS3 was automatically deleted. Reliability check for "Component1" delivered safely with Cronbach's alpha (0.775) while "Component2" had a low reliability with 0.653 prone to be deleted eventually.

Table 3.4 EFA for Independent Variable's Dimension of Personality (Conscientiousness)

\begin{tabular}{llllll}
\hline No. of Items & $\begin{array}{l}\text { Component } \\
\text { s }\end{array}$ & $\begin{array}{l}\text { No. of Items } \\
\text { in } \\
\text { component }\end{array}$ & $\begin{array}{l}\text { Eigenvalu } \\
\text { e }\end{array}$ & KMO & $\begin{array}{l}\text { Item(s) } \\
\text { Deleted }\end{array}$ \\
\hline $9 \quad$ items: & COMP1 & 3 & 3.125 & 0.696 & CONS2_r \\
CONS1,CONS3, & COMP2 & 4 & 1.614 & & CONS4_r, \\
CONS6,CONS7, & & & & CONS5_r, \\
CONS8,CONS2_r & & & & CONS9_r, \\
CONS4_r,CONS5_r & & & & CONS3 \\
CONS9_r & & & & \\
\hline
\end{tabular}

The second dimension of "Openness to Experience" has 10 items as: OPEN1, OPEN2, OPEN3, OPEN4, OPEN5, OPEN6, OPEN8, OPEN10, OPEN7_r and OPEN9_r. After EFA, the following results were obtained: a KMO (0.824), which is excellent, Barlett's test of Sphericity (Chi-square $=430.293$, $p$-value <0.000). Three (3) components are derived: "Component1" has OPEN1, OPEN3, OPEN4, OPEN5 and OPEN6 with Eigenvalue (4.472). "Component2" has OPEN9_r and OPEN10_r with Eigenvalue (1.353). And "Component3" was having OPEN2_r and OPEN7_r with Eigenvalue "1.035". Finally, OPEN8 was initially deleted from the EFA. Eventually, "Component1" delivered a Cronbach Alpha (0.872) which is more reliable. While "Component2" and "Component3" had low Cronbach's Alpha (0.682) and (0.419) respectively.

Table EFA for Independent Variable's Dimension of Openness to Experience

\begin{tabular}{|c|c|c|c|c|c|}
\hline No. of Items & $\begin{array}{l}\text { Component } \\
\text { s }\end{array}$ & $\begin{array}{l}\text { No. of Items } \\
\text { in } \\
\text { component }\end{array}$ & Eigenvalue & KMO & $\begin{array}{l}\text { Item(s) } \\
\text { Deleted }\end{array}$ \\
\hline 9 items: & COMP1 & 5 & 4.472 & 0.824 & OPEN2, \\
\hline OPEN1,OPEN2, & COMP2 & 2 & 1.353 & & OPEN7_r, \\
\hline $\begin{array}{l}\text { OPEN3, } \\
\text { OPEN4,OPEN5, }\end{array}$ & COMP3 & 2 & 1.035 & & $\begin{array}{l}\text { OPEN8, } \\
\text { OPEN9_r, }\end{array}$ \\
\hline OPEN6,OPEN7_r & & & & & OPEN10 \\
\hline \multicolumn{6}{|l|}{ OPEN8,OPEN9_r } \\
\hline OPEN10 & & & & & \\
\hline
\end{tabular}

The next dimension of "Extraversion" contains 8 indicators which are: EXT1, EXT3, EXT4, EXT6, EXT8, EXT2_r, EXT5_r and EXT7_r. The EFA resulted in the extraction of these factors as: "Component1" with EXT1, EXT3, EXT4, EXT6 and EXT8 under it, having Eigenvalue (3.243). "Component2" was having EXT2_r, EXT5_r and EXT7_r with Eigenvalue (1.788). The two components had a KMO value (0.706), which is a good one, and the Barlett's test of Sphericity showed (Chi-square $=307.325$, p-value < 0.000). The reliability of both components achieved significance with "Component1" with (0.830) Cronbach's Alpha and “Component2" with (0.735) Cronbach's Alpha. 
INTERNATIONAL JOURNAL OF ACADEMIC RESEARCH IN BUSINESS AND SOCIAL SCIENCES Vol. 8, No. 12, Dec, 2018, E-ISSN: 2222-6990 @ 2018 HRMARS

Table EFA for Independent Variable's Dimension of Personality (Extraversion)

\begin{tabular}{llllll}
\hline No. of Items & $\begin{array}{l}\text { Component } \\
\text { s }\end{array}$ & $\begin{array}{l}\text { No. of Items } \\
\text { in component }\end{array}$ & Eigenvalue & KMO & $\begin{array}{l}\text { Item(s) } \\
\text { Deleted }\end{array}$ \\
\hline $9 \quad$ items: & COMP1 & 5 & 3.243 & 0.706 & none \\
EXT1,EXT3, & COMP2 & 3 & 1.788 & & \\
EXT4,EXT6, & & & & & \\
EXT8,EXT2_r & & & & & \\
EXT5_r,EXT7_r & & & & & \\
\hline
\end{tabular}

Emotional Stability" dimension has 8 items and after it was run through EFA, it produced a KMO of (0.778). These items are EMS1, EMS3, EMS4, EMS6, EMS8, EMS2_r, EMS5_r and EMS7_r. The Barlett's test of Sphericity appeared as (Chi-square $=180.876, p$-value $<0.000$ ). The resulting components from the extraction are: "Component1" had EMS1, EMS3, EMS4, EMS6 and EMS8 having an Eigenvalue (2.938). While "Component2" had EMS2_r, EMS5_r and EMS7_r having an Eigenvalue (1.507). The reliability of EMS "Component1" showed Cronbach's Alpha (0.794), while "Component2" could not achieve reliability with low Cronbach's Alpha (0.457).

Table 3.7 EFA for Independent Variable's Dimension of Emotional Stability

\begin{tabular}{llllll} 
No. of Items & $\begin{array}{l}\text { Component } \\
\text { s }\end{array}$ & $\begin{array}{l}\text { No. of Items } \\
\text { in component }\end{array}$ & Egeinvalue & KMO & $\begin{array}{l}\text { Item(s) } \\
\text { Deleted }\end{array}$ \\
\hline $9 \quad$ items: & COMP1 & 5 & 2.938 & 0.778 & EMS2_r \\
EMS1,EMSS3, & COMP2 & 3 & 1.507 & & EMS5_r, \\
EMS4,EMS6, & & & & & EMS7_r, \\
EMS8,EMS2_r, & & & & & \\
EMS5_r & & & & & \\
EMS7_r & & & & & \\
\hline
\end{tabular}

\footnotetext{
"Agreeableness" has 9 items: AGR2, AGR4, AGR5, AGR7, AGR9, AGR1_r, AGR3_r, AGR6_rand AGR8_r. EFA of the factors eventually divided into three (3) components. The first Component has AGR6_r, AGR8_r and AGR1_r under it with Eigenvalue (3.146). The second Component consists of AGR2, AGR4, AGR9 and AGR3_r, with Eigenvalue (1.733). Lastly, the third Component comprises of AGR5, AGR7 with Eigenvalue (1.035). The items reached a KMO (0.699) which is satisfactory and a Barlett's test of Sphericity (Chi-square $=253.374, \mathrm{p}$ value $<0.000$ ). After the reliability test was conducted, "Component1" had Cronbach's Alpha (0.800), "Component2" had Cronbach (0.705), while "Component3" showed lesser reliability with (0.600) only.
} 
INTERNATIONAL JOURNAL OF ACADEMIC RESEARCH IN BUSINESS AND SOCIAL SCIENCES Vol. 8, No. 12, Dec, 2018, E-ISSN: 2222-6990 @ 2018 HRMARS

Table 3.8 EFA for Independent Variable's Dimension of Personality (Agreeableness)

\begin{tabular}{|c|c|c|c|c|c|}
\hline No. of Items & $\begin{array}{l}\text { Component } \\
\mathrm{s}\end{array}$ & $\begin{array}{l}\text { No. of Items } \\
\text { in component }\end{array}$ & Egeinvalue & KMO & $\begin{array}{l}\text { Item(s) } \\
\text { Deleted }\end{array}$ \\
\hline items: & COMP1 & 3 & 3.146 & 0.699 & AGR5, \\
\hline AGR2,AGR4, & COMP2 & 4 & 1.733 & & AGR7 \\
\hline AGR5, & COMP3 & 2 & 1.035 & & \\
\hline AGR7,AGR9, & & & & & \\
\hline AGR1_r & & & & & \\
\hline AGR3_r,AGR6_r & & & & & \\
\hline AGR8_r & & & & & \\
\hline
\end{tabular}

\section{Findings and Conclusion}

From the EFA results, the analysis revealed that conscientiousness and openness to experience are significant predictors. Most researches are consonant with the notion that entrepreneurs generally possess characteristics that improve their success, but contention still lies as to which of these characteristics more prominent in explaining entrepreneurial behavior. Therefore, this study revealed that conscientiousness and openness to experience were the only dimensions that significantly became relevant to the Bumiputra entrepreneurs and thus affect them significantly. Literature from previous studies has produced similar results, such as Mount et al., (1998) found conscientiousness, agreeableness and emotional stability were significant, while, Worrell and Cross Jr. (2004) study of African American students in a college in USA found agreeableness and openness not significant while the other Big Five personality characteristics were significant. Ciaverella et al., (2004) study proved that conscientiousness was positive while, extraversion, emotional stability and agreeableness negative. Zhao et al., (2010) meta-analysis was able to highlight that in most of the studies reviewed, conscientiousness and openness to experience proved to be significant predictor. Similarly, in Ismail et al., (2009) openness to experience and extraversion were significant. Patel and Thatcher (2012) study maintained that openness to experience was significant as the rest dimensions showed no significance. Zeffane (2013) found extraversion as significant.

In conclusion, these findings the Bumiputra Malays in Terengganu are generally more reserved just as expected by their communitarian society ethics and values which encourages one to be shy (Hamidon, 2009). According to Hamidon (2009), Malays values and traditions teach them politeness, courteousness and respectfulness. However, this raises the question whether the values conflict with the general notion of aggressiveness "survival of the fittest" thing of the current business world.

\section{References}

Abdullah, A. (2010). An empirical study on the factors influencing the success of planning approval of a development project: Malaysian context. (Unpublished doctoral dissertation). University of Malaya, Malaysia.

Ang, S. W \& Hong, D. G. P. (2000). Entrepreneurial spirit among east Asian Chinese. Ariff, M., \& Abubakar, S. Y. (2003). Strengthening entrepreneurship in Malaysia. Malaysian Institute of Economic Research, Kuala Lumpur, 1-22. 
INTERNATIONAL JOURNAL OF ACADEMIC RESEARCH IN BUSINESS AND SOCIAL SCIENCES Vol. 8, No. 12, Dec, 2018, E-ISSN: 2222-6990 C 2018 HRMARS

Awang, Z. (2012). Research methodology and data analysis. Penerbit Universiti Teknologi MARA Press.

Baum, J. R., Locke, E. A., \& Smith, K. G. (2001). A multidimensional model of venture growth. Academy of management journal, 44(2), 292-303.

Bird, B. (1988). Implementing entrepreneurial ideas: The case for intention. Academy of management Review, 13(3), 442-453.

Brockhaus, R. H., \& Horwitz, P. S. (1986). The psychology of the entrepreneur. Entrepreneurship: critical perspectives on business and management, 2, 260-83.

Brockhaus, R. H., \& Nord, W. R. (1979, August). An Exploration of factors affecting the entrepreneurial decision: Personal characteristic vs. environmental conditions. In Academy of Management proceedings (Vol. 1979, No. 1, pp. 364-368). Academy of Management.

Carraher, S. M., Buchanan, J. K., \& Puia, G. (2010). Entrepreneurial need for achievement in China, Latvia, and the USA. Baltic Journal of Management, 5(3), 378-396.

Ciavarella, M. A., Buchholtz, A. K., Riordan, C. M., Gatewood, R. D., \& Stokes, G. S. $\quad$ (2004). The Big Five and venture survival: Is there a linkage? Journal of Business Venturing, 19(4), 465483.

Costa Jr, P., Terracciano, A., \& McCrae, R. R. (2001). Gender differences in personality traits across cultures: robust and surprising findings. Journal of personality and social psychology, 81(2), 322.

Gomez, E. T. (2012). The politics and policies of corporate development: race, rents and redistribution in Malaysia. Malaysia's Development Challenges: Graduating from the Middle, 63-82.

Halim, M. A. S. A., Zakaria, Z., Hamid, A. C., \& Khalid, M. K. A. (2014). Fostering microentrepreneurship as panacea to poverty eradication in the Malaysian economy: $A$ conceptual perception. Asian Social Science, 10(13), 287-292. doi:10.5539/ass.v10n13p287

Halim, M. A. S. A., Zakaria, Z., Hasnan, M. T., \& Muda, S. (2012). The direction of Terengganu tourism industry in sustaining business growth: A conceptual framework. International Journal of Academic Research in Business and Social Sciences, 2(4), 250-263.

Hamidon, S. (2009). The Development of Malay Entrepreneurship in Malaysia. Unpublished Thesis. Massey University, Auckland, New Zealand.

Ismail, M., Khalid, S. A., Othman, M., Rahman, N. A., Kassim, K. M., \& Zain, R. S. (2009). Entrepreneurial intention among Malaysian undergraduates. International Journal of Business and Management, 4(10), 54-60.

John, O. P., Donahue, E. M., \& Kentle, R. L. (1991). The big five inventory-versions $4 a$ and 54.

Kalkan, M., \& Kaygusuz, C. (2012). The psychology of entrepreneurship. Edited by Thierry BurgerHelmchen, 1.

Ket De Vries, M. F. R. (1977). The entrepreneurial personality: a person at the crossroads. Journal of management studies, 14(1), 34-57. 
INTERNATIONAL JOURNAL OF ACADEMIC RESEARCH IN BUSINESS AND SOCIAL SCIENCES Vol. 8, No. 12, Dec, 2018, E-ISSN: 2222-6990 @ 2018 HRMARS

Khalique, M., Abdul, J., Shaari, N., \& Ageel, A. (2011). Challenges faced by the small and medium enterprises (SMEs) in Malaysia : An intellectual capital perspective. International Journal of Current Research, 3(6), 398-401.

Kitchell, S. (1997). CEO characteristics and technological innovativeness: A Canadian perspective. Canadian Journal of Administrative Sciences/Revue Canadienne des Sciences de I'Administration, 14(2), 111-121.

Klein, H. J. (1989). An integrated control theory model of work motivation. Academy of Management Review, 14(2), 150-172.

Koon, H. E. N. G. (1997). The new economic policy and the Chinese community in Peninsular Malaysia. The Developing Economies, 35(3), 262-292.

Lafaid, J. (1994). Attributtional style as a distinguishing factor of entrepreneurial achievement motivation. Unpublished Thesis. California School of Professional Psychology, Los Angeles.

Lumpkin, G. T., \& Dess, G. G. (1996). Clarifying the entrepreneurial orientation construct and linking it to performance. Academy of management Review, 21(1), 135-172.

Mansor, N., \& Ali, S. H. S. (2010). A B2C business agenda: Analyzing customers' perceptions towards Bumiputera retailers. Asian Social Science, 6(7), p132.

Markman, G. D., Baron, R. A., \& Balkin, D. B. (2005). Adversity quotient: Perceived perseverance and new venture formation. Unpublished manuscript presented at the Lenox-Darden Junior Faculty Retreat for Entrepreneurship Research. Martin, J. (2006). Persistence pays off for young entrepreneurs (Electronic version). Young Money, available at: www. youngmoney. com/entrepreneur/student_entrepreneurs/060401 (accessed January 26, 2007)

McClelland, D. C. (1961). The achieving society. Princeton, NJ: Van Nostrand

McGrath, R. G., MacMillan, I. C., Yang, E. A. Y., \& Tsai, W. (1992). Does culture endure, or is it malleable? Issues for entrepreneurial economic development. Journal of Business Venturing, 7(6), 441-458.

Morris, M. H., \& Sexton, D. L. (1996). The concept of entrepreneurial intensity: Implications for company performance. Journal of Business Research, 36(1), 5-13.

Mount, M. K., Barrick, M. R., \& Stewart, G. L. (1998). Five-factor model of personality and performance in jobs involving interpersonal interactions. Human performance, 11(2-3), 145165.

Naffziger, D. W., Hornsby, J. S., \& Kuratko, D. F. (1994). A proposed research model of entrepreneurial motivation. Entrepreneurship theory and practice, 18, 29-29.

Owens, K. S. (2003). An investigation of personality correlates of small business success.

Patel, P. C., \& Thatcher, S. M. (2012). Sticking It Out Individual Attributes and Persistence in SelfEmployment. Journal of Management, 40(7), 1932-1979.

Robinson, P. B., Stimpson, D. V., Huefner, J. C., \& Hunt, H. K. (1991). An attitude approach to the prediction of entrepreneurship. Entrepreneurship theory and practice, 15(4), 13-31.

Roddin, R., Sidi, N., Yusof, Y., Mohamed, M., \& Abdul Razaq A. (2011). Poverty alleviation among single mothers in Malaysia : Building entrepreneurship capacity. International Journal of Business and Social Science, 2(17), 92-100.

Sabiu, I. T., Abdullah, A. A., \& Amin, A. (2017). Impact Of Motivation And Personality Characteristics On Bumiputeras'entrepreneurial Persistence In Malaysia. Journal of Developmental 
INTERNATIONAL JOURNAL OF ACADEMIC RESEARCH IN BUSINESS AND SOCIAL SCIENCES Vol. 8, No. 12, Dec, 2018, E-ISSN: 2222-6990 C 2018 HRMARS

Entrepreneurship, 22(02), 1750009.Seibert, S. E., \& Lumpkin, G. T. (2009). The relationship of personality to entrepreneurial intentions and performance: A meta-analytic review. Journal of Management, 36(2), 381-404. doi:10.1177/0149206309335187

Scott, M. G., \& Twomey, D. F. (1988). The long-term supply of entrepreneurs: students' career aspirations in relation to entrepreneurship. Journal of small business management, 26(4), 5.

Sekaran, U. Bougie. R. (2013). Research methods for business. New York: John Wiley \& Sons, Inc. Sexton, D. L., \& Bowman, N. B. (1986). Validation of a personality index: Comparative psychological characteristics analysis of female entrepreneurs, managers, entrepreneurship students and business students. Frontiers of entrepreneurship research,

40-51.

Shaver, K. G., \& Scott, L. R. (1991). Person, process, choice: The psychology of new venture creation. Entrepreneurship theory and practice, 16(2), 23-45.

Sidek, S. \& Zainol, F. (2011). Psychological traits and business performance of entrepreneurs in small construction industry in Malaysia. International Journal of Business and Management, 2(1), 170-185.

Solomon, G. T., \& Winslow, E. K. (1988). Toward a descriptive profile of the entrepreneur. The Journal of Creative Behavior, 22(3), 162-171.

Thunderbird International Business Review, 42(3), 285-309.

Williams, D. E. (2011). The impact of personality on entrepreneurial intention and performance: Competing models and theory pruning (Doctoral dissertation, Indiana University).

Worrell, F. C., \& Cross, W. E. (2004). The reliability and validity of big five inventory scores with African American college students. Journal of Multicultural Counseling and Development, 32(1), 18-32.

Zamberi Ahmad, S., \& Xavier, S. R. (2012). Entrepreneurial environments and growth: evidence from Malaysia GEM data. Journal of Chinese Entrepreneurship, 4(1), 50-69. doi:10.1108/17561391211200939

Zeffane, R. (2013). Need for achievement, personality and entrepreneurial potential: A study of young adults in the United Arab Emirates. Journal of Enterprising Culture, 21(01), 75-105. doi:10.1142/S0218495813500040

Zhao, H., Seibert, S. E., \& Lumpkin, G. T. (2010). The relationship of personality to entrepreneurial intentions and performance: A meta-analytic review. Journal of management, 36(2), 381-404. 